\title{
An Assessment of Tourists' Shopping Experiential and Loyalty Intentions in Malaysian Outlet Shopping Malls
}

\author{
Fadhilah Zainal Abidin, Mazlina Mahdzar
}

To Link this Article: http://dx.doi.org/10.6007/IJARBSS/v10-i17/8499

DOI:10.6007/IJARBSS/v10-i17/8499

Received: 01 November 2020, Revised: 29 November 2020, Accepted: 28 December 2020

Published Online: 25 January 2021

In-Text Citation: (Abidin \& Mahdzar, 2021)

To Cite this Article: Abidin, F. Z., \& Mahdzar, M. (2021). An Assessment of Tourists' Shopping Experiential and Loyalty Intentions in Malaysian Outlet Shopping Malls. International Journal of Academic Research in Business and Social Sciences, 11(13), 21-32.

Copyright: (c) 2021 The Author(s)

Published by Human Resource Management Academic Research Society (www.hrmars.com)

This article is published under the Creative Commons Attribution (CC BY 4.0) license. Anyone may reproduce, distribute, translate and create derivative works of this article (for both commercial and non-commercial purposes), subject to full attribution to the original publication and authors. The full terms of this license may be seen at: http://creativecommons.org/licences/by/4.0/legalcode

Special Issue: Beyond 2021 and COVID-19 - New Perspective in the Hospitality \& Tourism Industry, 2021, Pg. 21 - 32

Full Terms \& Conditions of access and use can be found at http://hrmars.com/index.php/pages/detail/publication-ethics 


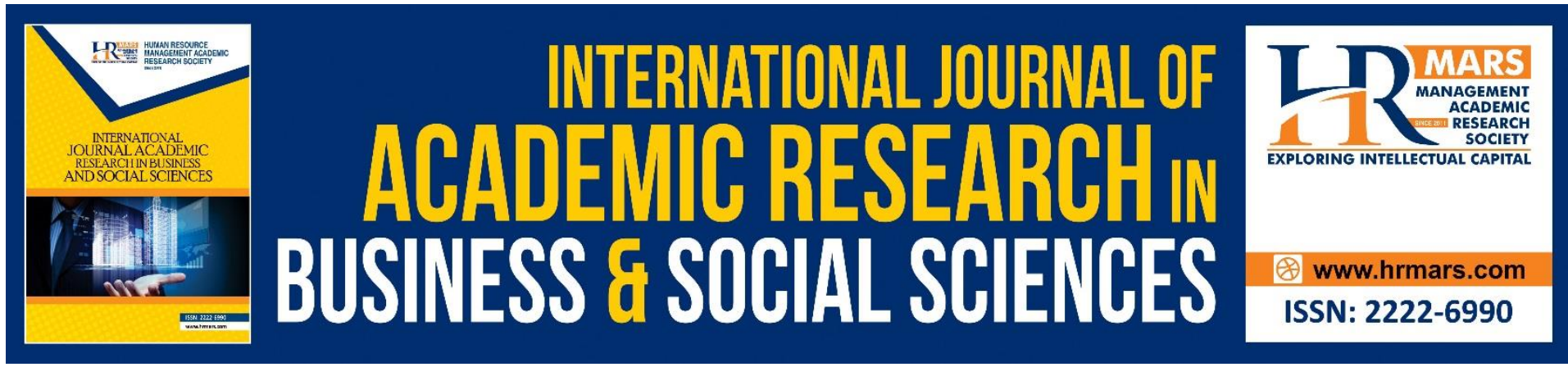

\title{
An Assessment of Tourists' Shopping Experiential and Loyalty Intentions in Malaysian Outlet Shopping Malls
}

\author{
Fadhilah Zainal Abidin, Mazlina Mahdzar \\ Faculty of Hotel and Tourism Management, Universiti Teknologi MARA, Selangor, Malaysia
}

\begin{abstract}
This study was conducted to empirically examine the effects of shopping tourism experiences on visitors' loyalty intentions at Gateway@KLIA2 and Mitsui Outlet Park, Sepang. Administrative questionnaires were distributed personally to 384 tourists using tablet google form. The data was analysed using the Statistical Program for the Social Science (SPSS) and Partial Least Squares -Structural Equation Modelling (PLS-SEM). Findings revealed that there is a significant relationship between tourists' shopping experience and loyalty intentions. The study concluded that understanding the tourist experiences based on experiential marketing or Strategic Experience Modules by Schmitt which are sensory, affective, intellectual, behaviour, and relational is beneficial for shopping mall operators and retail industry in Malaysia.
\end{abstract}

Keywords: Shopping Tourism, Tourist Experiences, Schmitt Experiential Marketing, Structural Equation Modelling, Loyalty Intentions.

\section{Introduction}

In Malaysia, the tourism industry is one of the major contributors to its economic development. The contribution derived from various tourism related commercial activities such as accommodation, transportation, recreation and shopping. Similar to other tourism products, shopping is considered as one of the fastest increasing segments and its outlay represents the second biggest share of tourist spending after accommodation (Bernama, 2016). In 2016, the income from shopping tourism increased by $17.1 \%$ within the first half year and the sector was making around RM11.7 billion (Bernama, 2016). According to UNWTO (2016), one of the top four best shopping cities in the world is Kuala Lumpur and there are three largest malls which are located within it (Kim \& Ritchie, 2014). Economic Census 2016's report by the Department of Statistics Malaysia (2018) proved that Selangor is the highest state that contributed to the tourism industry, followed by Kuala Lumpur and Johor.

Based on the record stated above, it is understandable that it must be quite challenging for the shopping mall providers to deliver their best services so that it creates memorable experiences for the customers. Kim and Ritchie (2014) claimed that the competitive marketplace in the 
tourism industry has influenced the interest of scholars on tourism experience research. A memorable experience given by the service providers has not only come from the products and services alone (Meyer \& Schwager, 2007). Apart from that, Quan and Wang (2004) agreed that tourists are constantly try to search for the best experience that they could have, hence fulfilling significantly their inner need in travelling and spending. This is also affirmed by Tung and Ritchie (2011) who proclaim that tourists look for various sceneries or landscapes, different cultures, and lifestyles of the locals at different tourism destinations. All of these has offered integrated experiences to tourists due to the unique delivering and memorable tourism experiences, and thus encouraged them to have loyalty intentions (Hudson \& Ritchie, 2009). Schmitt (1999) has introduced a framework of Strategic Experience Modules which focused on experiential marketing. This framework has helped some companies to have a better understanding on different delivery methods and experiences to the customers. Chang (2018) stated that tourists understand differently the meanings and values of the industry's tangible and intangible products. A whole new experience will be created once they have analysed and then reconstruct the experiences in their minds. There are various studies in various fields which have been conducted on tourists' experience. There are also number of scholars encouraged to test tourist experience instruments on different samples of tourists and travel segments. Thus, this study seeks to understand the effects of tourist experience and their loyalty intentions after their visits in the context of premium shopping outlet and airport shopping.

\section{Literature Review \\ Shopping Tourism}

Despite many destinations and activities that the tourists could enjoy during their tours, shopping seems to be one of the most important components which cannot be left out in the itinerary. A study by Henderson, Chee, Mun, and Lee (2011) revealed that in some cities, shopping is one of the main pulling factors that grab the tourists' attention. Cai, Lehto, and O'leary (2001) mentioned that shopping activities can also be one of the highest in terms of spending on their travel list. Based on Malaysia Tourist Profile (2013), shopping has become an important category of tourist activity in Malaysia. The amount that tourists spent on shopping is about the same as the money spent on the accommodation.

Mao-Ying Wu, Wall, and Pearce (2014) mentioned that tourists who visited attractions would definitely try to find time to do shopping especially on souvenirs for relatives, and others maybe just doing for some 'window shopping.'

There are many studies were conducted on various elements of shopping tourism. A few of interesting studies were completed by Bojanic (2011) on cross border shopping behaviours; Murphy, Benckendorff, Moscardo, and Pearce (2011) on visit shopping villages' motivations; Swanson and Timothy (2012) which elaborated on the meanings of souvenirs and their relation to sustainability; Lloyd, Yip, and Luk (2011) discussed on the shopping satisfaction among different tourist nationalities; as well as a study by Kim et al. (2011) which highlighted on the growing popularity of online shopping among travellers. Based on the researches, they have provided more findings on essential role of shopping in many tourists' experiences and the development of destinations. However, there are few studies have chosen shopping tourism that focus on outlet shopping mall concept. Outlet shopping mall concept is one of the visited 
attractions in tourism destinations that create an important element in the tourists' experience.

\section{Tourist Tourism Experience}

Lin and Kuo (2016) highlighted in their study that tourist experience and various choices of tourist destinations have become the main issue. Travelers would normally search for values and benefits that they may get in the destination chosen by them. Pine and Gilmore (1998) pointed out that the concept and relationship to experience must be parallel to the economy of experience. This message obviously leads to the researcher's attention to include user or tourist experience in their future study. Meyer and Schwager (2007) stated that high-quality tourism products or services are not necessarily bring an extraordinary experience to the tourists. In certain situations, tourist's main goal is to search for the ultimate experience, where their inner need for experience becomes more important than the high quality of products (Quan and Wang, 2004). Pine and Gilmore (1998) mentioned previously that tourists will achieve the best experience if they join enthusiastically in the activity. It is essential to produce a memorable sensation along with product differentiation that can lead to satisfaction, and consumers can evaluate the high or low values gained from the usefulness of the product (Sahiraliani, 2013; Rosanti, 2014). In other words, when the value is higher, consumers who consume the products will have more satisfaction and vice versa. Lemon and Verhoef (2016) added that tourism shopping experiences may also relate to shopping environment, typology of tourists, services and product attributes, as well as the entire perceptions of the products, services, and place.

\section{Schmitt's Concept}

Lemon and Verhoef (2016) described that Schmitt (1999) was among the first scholars who emphasized customer experience's significance. He used a multi-dimensional assessment and recognized five kinds of experiences or the five strategic experiential modules (SEM) which are sensory (sense), affective (feel), cognitive (think), physical (act), and social-identity (relate) experiences. The first element which is sensory, is focused on both visual and non-visual senses because they are considered as essential components in the tourists' experiences (Agapito, Mendes \& Valle, 2013). According to Rodríguez-Santos, González-Fernández, and Cervantes-Blanco (2013), the cognitive as second element is known to have relation with one's knowledge and beliefs about any destinations. Some of the elements of cognitive that involved with tourists' experiences are perception (Gil \& Droit-Volet, 2009) which involved the way of thinking, choosing, and learning. Then, the third element which is affective, can be understood into two groups that include basic emotions and other detailed affective stages (Pharino et al., 2018). Fredrickson (2001) highlighted that the act is also relevant to the numerous tourism settings, and these involved the moods of happiness, joy, fear and surprise. This is also supported by Pearce (2011) that the enjoyment, excitement, love, sympathy, and indifference influenced by the same factor. Apart from that, he identified behavioural as the element which implicates more on what people normally or will do on site. From the study, there is also a relation between tourist behaviour and technology used, for example, the people's movement, and their specific behaviour or actions such as self-taking pictures, do videos' recording, chatting, and others. Pearce, Wu, De Carlo, and Rossi (2013) outlined on the closeness and experience of going holiday with friends or family may give different impacts compares to travel in groups, with people who are totally strangers or solo travellers. 


\section{Loyalty Intentions}

According to Zhang, Fu, Cai, and Lu (2014), there are several elaborations on loyalty intentions. The tourists' attitude is depending on the value of a product or service that they get, which lead them to have the intention to repurchase. They pointed out that loyalty can be classified as behaviours which will encourage the tourist to recommend to others about the destination or products and services. Reichheld (2001) in the study noted that customer loyalty will boost the profit of the company. Oliver (1999) described that loyalty is an approach to re-buying or re-using a product or service constantly in future even though the competitors are trying hard to change that. Suhartanto and Triyuni (2016) mentioned on due to the behavioural and attitudinal limitations, numbers of experts in tourism marketing recommend a blend of these two approaches. This is because loyalty towards a destination by tourists is analysed by using their actual visit to the destinations, their intention to revisit in the future and the intention to recommend the destination to other people.

Aligning to that, behavioural intentions can be considered as one of the elements which wellrepresent the customer loyalty as expressed in a study by Zeithaml, Berry, and Parasuraman (1996). Adding to that, some literatures has revealed that customer perceived value has a direct relationship on loyalty intention. Also, the positive results that derived from behavioural intentions consist of distribution positive word of mouth (WoM), recommendations to friends and family, repeat of tour, purchasing the same product/service and paying the items at the best price. Jones and Taylor (2007) added that there are two elements of loyalty which are the behavioural (for example, repurchase intentions) and attitudinal (for example, the willingness to recommend). Baker and Crompton (2000) supported the approach of revisit intentions as one of the possibilities for tourist to repeat activity and revisit a destination. If the tourists have good experience at the destination, they may select the options to return, promote to the friends and relatives or recommend to others (Yoon \& Uysal, 2005; Hung \& Petrick, 2012). Sheorey (2014) stated Besides product quality or service offered to the consumers seem to be important, 'value-added services' is also element that should be taken into account (Sheorey, 2014). Therefore, it is important for retailers of shopping malls to concentrate on the visitor experiences and their loyalty intentions which will benefit their businesses.

\section{The Relationship between Tourism Experiences and Loyalty Intentions}

Lin and Kuo (2016) revealed that the connection between experience and loyalty is used and contributed to the literature. One of the studies found that loyalty has influenced the brand experience (Brakus et al.; 2009). Meanwhile, in some other relationships, the word-of-mouth and loyalty behaviours were influenced by the service experience (Klaus \& Maklan; 2012). According to Han and Back (2008), tourists' emotional experiences will affect intentions to revisit. Besides, the quality of previous experience can also determine tourists' intention to revisit to the destination (Kim and Ritchie; 2014). Behavioural intention to revisit a destination can be enhanced if the management provide their visitors with a good memorable experience. The satisfaction, positive experiences or pleasurable outcomes and stimulations on previous visits will influence their visit intentions (Marschall, 2012; Mahdzar et. al, 2017; Brakus et al., 2009) Due to that, tourism experience should touch not only past-directed satisfaction decisions but also future-directed consumer loyalty. Tourists who visited and have positive experience in any attractions including shopping outlets or malls should be more likely to 
come again and recommend to others. Therefore, this study hypothesized that the five dimensions of tourism experiences (i.e. sensory, affective, behavioural, intellectual and relational) will significantly influence on loyalty intentions as follows:

$\mathrm{H}_{1}$. Tourists experience has significant effect on loyalty intentions

$\mathrm{H}_{1 \mathrm{a}}$. Sensory in tourists' experiences have significant effect on loyalty intentions.

$\mathrm{H}_{1 \mathrm{~b}}$. Affective in tourists' experiences have significant effect loyalty intentions.

$\mathrm{H}_{1 c}$. Behavioural in tourists' experiences have significant effect on loyalty intentions.

$\mathrm{H}_{1 \mathrm{~d}}$. Intellectual in tourists' experiences have significant effect on loyalty intentions.

$\mathrm{H}_{1 \mathrm{e}}$. Relational in tourists' experiences have significant effect on loyalty intentions.

\section{Methodology}

The data was collected from visitors who did their shopping activities at several spots in Gateway@KLIA2 and Mitsui Outlet Park, Sepang. The study was carried out by using tablet devices where respondents were required to key in their answers. The researcher used Google Form to replace the traditional technique (paper and pen) as it is more convenient and can prevent missing information. A total of 384 questionnaires were distributed to shoppers, completed and used for analysis. Out of these respondents, $35.9 \%$ were male whereas $64.1 \%$ were female. $63 \%$ were in the age range between $28-37$ years, $24.5 \%$ were between $18-27$ years and $12.5 \%$ were older than $38-47$ years. $38.5 \%$ of the total respondents had monthly income of above RM5000, 28.6\% had monthly income between RM3001 to RM5,000 and $20.3 \% \%$ had monthly income between RM1000 - RM3000, and $12.5 \%$ stated their income as not applicable. 52.3\% were local (Malaysians), whereas $47.4 \%$ were foreigners. The data was analysed using SPSS and SEM-PLS. To assess the measurement model, the research conducted a confirmatory factor analysis (CFA) with reliability and construct validity checks. To assess the structural model and test hypotheses, structural equation modelling - partial least squares (SEM-PLS) was conducted as recommended by Anderson and Gerbing (1988).

\section{Result and Analysis}

All standardized factor loading of each construct was above 0.700 that confirmed the convergent validity. Composite reliability for six latent constructs was between 0.862 and 0.953 that showed the internal consistency (See Table 1). The average variance extracted (AVE) from all constructs exceeded the cut-off criterion of 0.500 . 
Table 1: Validity and reliability for constructs.

\begin{tabular}{|c|c|c|c|}
\hline & $\begin{array}{l}\text { Factor } \\
\text { loadings }\end{array}$ & CR & AVE \\
\hline SENSORY (SEN) & & $0.914 * * *$ & $0.642 * * *$ \\
\hline SEN1 & 0.820 & & \\
\hline SEN2 & 0.844 & & \\
\hline SEN3 & 0.873 & & \\
\hline SEN4 & 0.856 & & \\
\hline SEN6 & 0.827 & & \\
\hline AFFECTIVE & & $0.943^{* * *}$ & $0.733 * * *$ \\
\hline \multicolumn{4}{|l|}{ (AFF) } \\
\hline AFF2 & 0.850 & & \\
\hline AFF3 & 0.856 & & \\
\hline AFF4 & 0.848 & & \\
\hline AFF5 & 0.902 & & \\
\hline AFF6 & 0.900 & & \\
\hline $\begin{array}{l}\text { INTELECTUAL } \\
\text { (INT) }\end{array}$ & & $0.904^{* * *}$ & $0.615^{*}$ \\
\hline INT1 & 0.877 & & \\
\hline INT3 & 0.897 & & \\
\hline INT4 & 0.769 & & \\
\hline INT5 & 0.827 & & \\
\hline INT6 & 0.734 & & \\
\hline BEHAVIOUR & & $0.862 * * *$ & $0.523 * * *$ \\
\hline \multicolumn{4}{|l|}{ (BEH) } \\
\hline BEH1 & 0.944 & & \\
\hline BEH2 & 0.888 & & \\
\hline BEH6 & 0.782 & & \\
\hline RELATIONAL & & $0.933 * * *$ & 0.699* \\
\hline \multicolumn{4}{|l|}{ (REL) } \\
\hline REL1 & 0.865 & & \\
\hline REL2 & 0.886 & & \\
\hline REL4 & 0.805 & & \\
\hline REL5 & 0.925 & & \\
\hline LOYALTY & INTENTION & $0.953 * * *$ & $0.720 * * *$ \\
\hline \multicolumn{4}{|l|}{ BEHAVIOUR (LIB) } \\
\hline LIB1 & 0.909 & & \\
\hline LIB3 & 0.813 & & \\
\hline LIB4 & 0.788 & & \\
\hline LIA1 & 0.939 & & \\
\hline LIA2 & 0.950 & & \\
\hline LIA3 & 0.847 & & \\
\hline LIA4 & 0.909 & & \\
\hline
\end{tabular}

This research was subsequently tested for the structural model and hypotheses. The corrected $\mathrm{R}^{2}$ refer to the explanatory power of the predictor variables on the respective construct. $81.2 \%$ 
$\left(R^{2}=0.812\right)$ of tourists' loyalty intentions can be predicted by sensory, affective, intellectual, behavioural and relational in tourist shopping experience. Based on the model validity, Chin et al. (2008) classified endogenous latent variables as substantial, moderate or weak based on the $\mathrm{R}^{2}$ values of $0.67,0.33$, or 0.19 , respectively. Hence, all the five dimensions in tourist experience; sensory (0.001), affective (0.048), intellectual (0.013), behavioural (0.050) and relational $(0.024)$ has indicated weak effect sizes towards loyalty intentions.

In addition, the complete results of the structural model and hypotheses testing are presented in Table 2. Three hypotheses ( $\mathrm{H} 1, \mathrm{H} 1 \mathrm{~b}$, and $\mathrm{H} 1 \mathrm{c})$ were supported, showing that tourism shopping experience of affective and behaviour are good predictors of tourists' shopping experience and their loyalty intentions to patronage. Additionally, the findings also depicted that tourists' tourism shopping experience is a significant predictor of their loyalty patronage intentions.

Table 2: Structural estimates (hypotheses testing)

\begin{tabular}{llllll}
\hline Hypotheses & Path & $\begin{array}{l}\text { Standard } \\
\text { Beta }\end{array}$ & T-Statistics & p-value & Decision \\
\hline $\mathrm{H} 1$ & $\begin{array}{l}\text { Shopping } \\
\text { Tourism } \\
\text { Experience }\end{array}$ & 0.402 & 6.301 & 0.000 & Supported \\
& $\begin{array}{l}\boldsymbol{\text { Loyalty }} \\
\text { Intentions }\end{array}$ & & & & \\
& $\mathrm{SEN} \rightarrow$ LIB & 0.038 & 1.020 & 0.300 & Not Supported \\
$\mathrm{H} 1 \mathrm{a}$ & $\mathrm{AFF} \Rightarrow$ LIB & 0.225 & 4.963 & 0.000 & Supported \\
$\mathrm{H} 1 \mathrm{~b}$ & $\mathrm{BEH} \rightarrow$ LIB & 0.157 & 2.726 & 0.000 & Supported \\
$\mathrm{H} 1 \mathrm{c}$ & $\mathrm{INT} \rightarrow$ LIB & 0.002 & 0.161 & 0.872 & Not Supported \\
$\mathrm{H} 1 \mathrm{~d}$ & $\mathrm{REL} \rightarrow$ LIB & 0.135 & 1.874 & 0.061 & Not Supported \\
$\mathrm{H} 1 \mathrm{e}$ & & & &
\end{tabular}

\section{Discussion and Conclusion}

Among the five dimensions in Schmitt's' experiential marketing or strategic experience modules, the first two dimensions; affective and behaviour have the significant to loyalty intentions and this followed with relational, intellectual and relationship as insignificant dimensions. Affective dimension in tourists' experiences contributed the highest significance to loyalty intentions due to $\beta=0.225, t=4.963$. This can be understood where the tourists were happy with the facilities and amenities provided, decorations and surrounding. Besides, they agreed that they made the right decision to visit the malls and gained positive feelings because of the personnel's friendliness. Hence, shopping mall providers should strive at creating emotional attraction from moderate positive moods to powerful feelings of happiness and pride. Shopping mall operators are expected to cater for more entertainment activities and occasions by inviting celebrities, Korean pop boy group, local festivals and cultural activities that will emotionally enhance visitors' desire to visit shopping malls (Devi Juwaheer, Pudaruth, \& Ramdin, 2013).

Furthermore, behaviour experience was the second highest significance to loyalty intentions as $\beta=0.157, t=2.726$. This can be related to the time when the tourists would like to know more about the shopping mall details, reminded them of activities that they can do and the promotion the shopping outlets had held. These would encourage them to purchase more in 
the outlets. Despite of all these, the tourists experienced less engagement and would not prefer to ask the receptions or check out the websites during their trip. They less favoured in any physical actions and behaviour when they were in the shopping malls. Therefore, Schmitt, Rogers, and Vrotsos (2003) suggested that shopping mall operators may consider providing visitors with guidelines or establish working item links to the pictures so that customers can discover the products and encourage further browsing. Thus, getting illustrations of the products on the pages may boost the intentions of consumers to buy. The study, however, found that sensory, intellectual and relational dimensions of experiential marketing were not significant predictor to loyalty intentions.

The current study highlighted on several important issues including to examine the concept of tourist shopping experience in the context of Malaysian outlet shopping malls. Some of the limitations of this study may guide to the future research. Since the study employed convenience sampling, the generated results cannot be generalized. For instance, the findings of this study should be interpreted with caution when applied to different types of shopping malls or at different states. Future research should be extended to examine the proposed relationships in shopping malls of different categories and at distinct times of the year, or on distinct population backgrounds.

\section{Corresponding Author}

Mazlina Mahdzar. Faculty of Hotel and Tourism Management, Universiti Teknologi MARA, Puncak Alam Campus, 42300, Puncak Alam, Selangor, Malaysia.

E-mail:nina@uitm.edu.my

\section{References}

Agapito, D., Mendes, J., \& Valle, P. (2013). Exploring the conceptualization of the sensory dimension of tourist experiences. Journal of Destination Marketing and Management, 2(2), 62-73.

Anderson, J. C., \& Gerbing, D. W. (1988). Structural equation modelling in practice: A review and recommended two-step approach. Psychological Bulletin, 103(3), 411.

Baker, D. A., and Crompton, J. L. (2000). Quality, satisfaction and behavioural intentions. Annals of Tourism Research, 27(3), 785-804.

Bernama. (2016). National revenue from 'shopping tourism' rises by 17.1 percent. Retrieved from http://english.astroawani.com/business-news/nationalrevenue-shoppingtourism-rises-17-1-percent-121746

Bojanic, D. C. (2011). The impact of age and family life experiences on Mexican visitor shopping expenditures. Tourism Management, 32(2), 406-414.

Brakus, J. J., Schmitt, B. H., \& Zarantonello, L. (2009). Brand experience: what is it? How is it measured? Does it affect loyalty? Journal of Marketing, 73(3), 52-68.

Chang, S. (2018). Experience economy in hospitality and tourism: Gain and loss values for service and experience. Tourism Management, 64, 55-63.

Chin, W. W. (1998a). The partial least squares approach to structural equation modelling. Modern Methods for Business Research, 295(2), 295-336.

Cai, L. A., Lehto, X. Y., \& O'leary, J. (2001). Profiling the US-bound Chinese travellers by purpose of trip. Journal of Hospitality and Leisure Marketing, 7(4), 3-16.

Department of Statistics Malaysia. (2018). Press Release Economic Census 2016: Tourism Statistics. Retrieved from 
https://www.dosm.gov.my/v1/index.php?r=column/pdfPrev\&id=VmZsbTU4NDIFcFZRd VF6ZDF30W4zZz09

Department of Statistics Malaysia. (2018). Tourism Satellite Account 2017. Retrieved from https://www.dosm.gov.my/v1/index.php?r=column/cthemeByCat\&cat=111\&bul_id=Yl U1d29XWW1kRUtBVWVuMS9IcUZ3QT09\&menu_id=TE5 CRUZCblh4ZTZMODZIbmk2aWRRQT09.

Fredrickson, B. L. (2001). The role of positive emotions in positive psychology: The broadenand-build theory of positive emotions. American Psychologist, 56(3), 218.

Gil, S., \& Droit-Volet, S. (2009). Time perception, depression and sadness. Behavioural Processes, 80(2), 169-176.

Han, H., \& Back, K. (2008), Relationships among image congruence, consumption emotions, and customer loyalty in the lodging industry. Journal of Hospitality and Tourism Research, (32) 4, 467-490.

Henderson, J. C., Chee, L., Mun, C. N., \& Lee, C. (2011). Shopping, tourism, and retailing in Singapore. Managing Leisure, 16, 36-48.

Hudson, S., \& Ritchie, J. B. (2009). Branding a memorable destination experience. The case of 'Brand Canada'. International Journal of Tourism Research, 11(2), 217- 228.

Hung, K., \& Petrick, J. F. (2012). Testing the effects of congruity, travel constraints, and selfefficacy on travel intentions: An alternative decision-making model. Tourism Management, 33(4), 855-867.

Jones, T., \& Taylor, S. F. (2007). The conceptual domain of service loyalty: how many dimensions? Journal of Services Marketing, 21(1), 36-51.

Kim, J.-H., \& Ritchie, J. B. (2014). Cross-cultural validation of a memorable tourism experience scale (MTES). Journal of Travel Research, 53(3), 323-335.

Kim, M.-J., Chung, N., \& Lee, C.-K. (2011). The effect of perceived trust on electronic commerce: Shopping online for tourism products and services in South Korea. Tourism Management, 32(2), 256-265

Klaus, P., \& Maklan, S. (2012). Towards a better measure of customer experience. International Journal of Market Research, (55)2, 227-246.

Lemon, K. N., \& Verhoef, P. C. (2016). Understanding customer experience throughout the customer journey. Journal of Marketing, 80(6), 69-96.

Lin, C.-H., \& Kuo, B. Z.-L. (2016). The behavioural consequences of tourist experience. Tourism Management Perspectives, 18, 84-91.

Lloyd, A. E., Yip, L. S., \& Luk, S. T. (2011). An examination of the differences in retail service evaluation between domestic and tourist shoppers in Hong Kong. Tourism Management, 32(3), 520-533.

Mahdzar, M., Izhar, F. S., Wee, H., Ghani, A. A., Hamid, Z. A., \& Anuar, N. A. M. (2017). Measuring Experience Economy and Satisfaction: An Examination of Visitors in Agricultural Park. Advanced Science Letters, 23(8), 7574-7577.

Marschall, S. (2012). 'Personal memory tourism' and a wider exploration of the tourismmemory nexus. Journal of Tourism and Cultural Change, 10(4), 321- 335.

Meyer, C., \& Schwager, A. (2007). Understanding customer experience. Harvard Business Review, 85(2), 116.

Murphy, L., Moscardo, G., Benckendorff, P., \& Pearce, P. (2011). Evaluating tourist satisfaction with the retail experience in a typical tourist shopping village. Journal of Retailing and Consumer Services, 18(4), 302-310. 
Oliver, R. L. (1999). Whence Customer Loyalty. Journal of Marketing, 63, Special Issue, 33-44

Pearce, P. L. (2011). Tourist Behaviour and the Contemporary World (Vol. 51): Channel view publications.

Pearce, P. L., Wu, M.-Y., De Carlo, M., \& Rossi, A. (2013). Contemporary experiences of Chinese tourists in Italy: An on-site analysis in Milan. Tourism Management Perspectives, 7, 3437.

Pharino, C., Pearce, P., \& Pryce, J. (2018). Paranormal tourism: Assessing tourists' onsite experiences. Tourism Management Perspectives, 28, 20-28.

Klaus, P., \& Maklan, S. (2012). EXQ: a multiple-item scale for assessing service experience. Journal of Service Management, 23(1), 5-33.

Pine, B. J., \& Gilmore, J. H. (1998). Welcome to the experience economy. Harvard Business Review, 76, 97-105.

Pizam, A., Chon, K. S., \& Mansfeld, Y. (1999). Consumer Behaviour in Travel and Tourism: Psychology Press.

Quan, S., \& Wang, N. (2004). Towards a structural model of the tourist experience: An illustration from food experiences in tourism. Tourism Management, 25(3), 297- 305.

Reichheld, F. F. (2001). Loyalty Rules: How Today's Leaders Build Lasting Relationships: Harvard Business Press.

Rodríguez-Santos, M. C., González-Fernández, A. M., \& Cervantes-Blanco, M. (2013). Weak cognitive image of cultural tourism destinations. Quality and Quantity, 47(2), 881-895.

Rosanti, N. (2014). Pengaruh Experiential Marketing Dan Experiential Value Terhadap Customer Satisfaction (Survei Pada Mahasiswa Fia Bisnis 2013/2014 Pengguna Android Samsung). Jurnal Administrasi Bisnis, 16(1).

Sahiraliani, D. (2013). Pengaruh experiential marketing terhadap kepuasan konsumen Starbucks di Kota Bandung

Schmitt, B. H. (1999) Experiential Marketing. How to Get Customers to Sense, Feel, Think, Act, Relate to Your Company and Brands. The Free Press, New York.

Schmitt, B., Rogers, D., \& Vrotsos, K. (2003). There's No Business That's Not Show Business: Marketing in an Experience Culture: FT Press.

Sheorey, P. (2014). An analysis of customer engagement management using the experiential marketing approach in the loyalty card industry

Suhartanto, D., \& Triyuni, N. N. (2016). Tourist loyalty toward shopping destination: the role of shopping satisfaction and destination image. European Journal of Tourism Research, $13,84$.

Swanson, K. K., \& Timothy, D. J. (2012). Souvenirs: Icons of meaning, commercialization and commoditization. Tourism Management, 33(3), 489- 499.

Tung, V. W. S., \& Ritchie, J. B. (2011). Exploring the essence of memorable tourism experiences. Annals of Tourism Research, 38(4), 1367-1386.

World Tourism Organization. (2016), UNWTO Tourism Highlights, 2016 Edition, UNWTO. Retrieved from https://www.e-unwto.org/doi/pdf/10.18111/9789284418145

World Tourism Organization. (2018), UNWTO Tourism Highlights, 2018 Edition, UNWTO, Madrid, DOI: https://doi.org/10.18111/9789284419876.

Yoon, Y., \& Uysal, M. (2005). An examination of the effects of motivation and satisfaction on destination loyalty: a structural model. Tourism Management, 26(1), 45-56.

Zeithaml, V. A., Berry, L. L., \& Parasuraman, A. (1996). The behavioural consequences of service quality. Journal of Marketing, 60(2), 31-46. 
INTERNATIONAL JOURNAL OF ACADEMIC RESEARCH IN BUSINESS AND SOCIAL SCIENCES

Vol. 11, No. 13, Beyond 2021 and COVID-19 - New Perspective in the Hospitality \& Tourism Industry. 2021, E-ISSN: 2222-6990 @ 2021 HRMARS

Zhang, H., Fu, X., Cai, L. A., \& Lu, L. (2014). Destination image and tourist loyalty: A metaanalysis. Tourism Management, 40, 213-223. 